\title{
Equity Entry Mode and Enterprise Performance: A Meta-Analysis
}

\author{
Tingya Zhang \\ Business School, Nanjing Normal University, Nanjing, China \\ Email: bydncherry@163.com
}

How to cite this paper: Zhang, T.Y. (2019) Equity Entry Mode and Enterprise Performance: A Meta-Analysis. Open Journal of Social Sciences, 7, 210-222.

https://doi.org/10.4236/jss.2019.712016

Received: November 1, 2019

Accepted: December 10, 2019

Published: December 13, 2019

Copyright $\odot 2019$ by author(s) and Scientific Research Publishing Inc. This work is licensed under the Creative Commons Attribution International License (CC BY 4.0).

http://creativecommons.org/licenses/by/4.0/

\begin{abstract}
The choice of entry mode, especially the choice between sole proprietorship and joint venture, is one of the important strategic decisions for multinational corporations to make foreign direct investment. Although there have been a large number of empirical studies on the relationship between entry mode and enterprise performance, the existing studies have not reached a more consistent conclusion on the relationship between them and the influencing factors affecting the relationship between them. This paper selects 58 independent empirical studies, and uses the Meta-analysis method to integrate the empirical results, and obtains the comprehensive results that the equity entry mode has a significant impact on corporate performance. At the same time, the study also found that the relationship between equity entry mode and enterprise performance is affected by the degree of development of the source country and host country, enterprise size and other factors.
\end{abstract}

\section{Keywords}

Entry Mode, Performance, Meta-Analysis, Emerging Economies

\section{Introduction}

Under the tide of economic globalization, more and more enterprises go to the international market and compete in a larger market range. The share of foreign investment in global FDI by developing economies has reached an all-time high of 66 percent as a result of the sharp decline in foreign investment absorbed by developed countries, according to a report released by the United Nations Trade and Development Organization in October 2018. Half of the world's top 10 foreign capital inflows are destined for developing economies. Thus it can be seen that the global outbound investment has changed dramatically, and the developing countries have occupied a very important position as the host country of 
enterprises' outbound investment.

In the process of enterprise internationalization, enterprises will face the choice of entry mode. Entry mode is the cornerstone of multinational corporations' market entry strategy. In the face of the complex and changeable foreign investment environment, the rationality and effectiveness of the entry mode of overseas investment market will directly affect the performance of enterprises. Whether it adopts the new green space of the host country or the direct acquisition of the host country enterprise, or through the wholly owned hierarchical governance model or the joint venture mixed governance model, There are great differences in the resources, technology, manpower and risks that enterprises need to invest after making the choice of entry mode, so it will have different effects on the performance of multinational enterprises. In addition to the internal factors of the enterprise that will affect the performance of multinational enterprises, external factors such as the economic environment of the host country will also have an impact on the performance of overseas investment of multinational enterprises. Therefore, there is a contingency relationship between the entry mode of overseas investment market and the level of enterprise performance. What kind of entry mode enterprises adopt will have a vital impact on the success of enterprises, so that Wind and Perlmutter (1977) define entry mode as the frontier issue of international marketing [1]. Foreign direct investment is one of the important means for enterprises to enter the international market.

Many scholars at home and abroad have studied the relationship between entry mode and business performance, but many studies are based on different theories and from different perspectives. Therefore, the conclusions of the relationship between the two are not consistent, even if some studies use the same theory to explain, the conclusions may be inconsistent, or even the opposite. At the same time, the research literature on the entry mode and performance of overseas investment market is rich, which meets the objective conditions for meta-analysis. Therefore, this paper plans to use the method of meta-analysis to study. Not only the subjectivity of qualitative literature research can be avoided, but also the overall estimated results can be obtained through the quantitative integration of the existing research results, and the sources of differences between different literature research results can be found. Therefore, this study itself has important theoretical innovation significance.

\section{Theoretical Summary and Hypothesis}

\subsection{The Relationship between Equity Entry Mode and Enterprise Performance}

The entry mode of enterprises' foreign investment is an important research field. Stopford and wells (1972) is considered to be an early scholar to study this issue. They summarized several entry modes of enterprise internationalization choice, but did not analyze and explain the theoretical basis of this choice [2]. The early scholars' theoretical research on the entry mode of cross-border investment mar- 
ket is mostly based on the theory of overseas direct investment, the main research object is the developed countries, and the developing countries are less involved, forming a series of representative theories. Before the 1990s, the monopoly advantage theory of Hymer (1960), the internalization theory of Buckley and Casson (1976) [3] and the international production compromise theory of Dunning (1977) [4] were the most representative. The theory of monopoly advantage emphasizes that the decisive factor affecting the international expansion behavior of enterprises is monopoly advantage, and puts forward for the first time that the overseas investment market should take the market imperfect competition as the starting point, that is, only the market is in an imperfect state. Only then can the enterprise carry on the marginal expansion by virtue of its own monopoly advantage. The essence of internalization theory is the expansion of enterprise management and control based on ownership. It mainly focuses on the transaction costs of enterprises operating in overseas markets, and believes that the incompleteness of market information in the host country and the uncertainty of intermediate product prices will make enterprises bear higher transaction costs. As a result, multinationals can internalize transactions to reduce costs and improve corporate profitability. The theory of international production compromise synthesizes the theoretical achievements of its predecessors, and holds that the enterprise's international direct investment is determined by three basic factors: ownership advantage, internalization advantage and location advantage, and a more complete explanation and analysis of the motivation, direction and location choice of overseas investment.

The early research on the choice of entry mode of overseas investment market tends to the perspective of transaction cost. Transaction cost theory shows that under the condition of imperfect competitive market, enterprises will try to minimize costs and maximize benefits in the process of internationalization. In the early stage, the people who really began to apply the transaction cost theory to the choice of entry mode were Anderson and Gatignon (1986) [5], who took the transaction cost as the main research object. On this basis, this paper constructs the analysis framework of the entry mode of enterprises' overseas investment market, and focuses on the circumstances under which multinational enterprises can choose which strategic model to maximize the rate of return on investment. In the real sense, the theory of transaction cost is put forward by Willianmson $(1975,1985)$ [6] [7]. He points out that there is a positive correlation between the specificity of assets and the uncertainty of transaction and the degree of control of the entry mode of overseas investment market. That is, the higher the degree of specificity of assets, the more uncertain factors in trading, the more easily the agency problem of enterprises is affected, and the phenomenon of "hitchhiking" will become more and more serious. Therefore, enterprises are more inclined to choose a highly controlled mode of entry into overseas investment.

After the 1990s, the environmental uncertainty faced by multinational corporations is increasing day by day. From the perspective of transaction cost, we pay too much attention to the negative impact of opportunism and internal and ex- 
ternal uncertainty. However, it does not take into account the opportunity cost of entering the overseas investment market and the choice of entry mode, and neglects the value creation potential of overseas investment under uncertain conditions. Therefore, Kogut (1991) [8] and other scholars have introduced the real option theory, which is suitable for solving the problem of strategic investment under uncertain conditions, and gradually developed into a real option perspective. From this perspective, the strategic adaptability of multinational enterprises under uncertain conditions is increasingly becoming the key to the construction of sustainable competitiveness, and the overseas investment market behavior of enterprises is essentially a collection of strategic choice rights. Its strategic flexibility and effective management in different real option combinations is the source of its competitiveness.

With the development of economic globalization and information technology, the breadth and depth of enterprise internationalization continue to improve, and the complex uncertainty caused by multiple institutional environment has a more and more important impact on the choice of overseas investment entry mode. Based on different theoretical bases and research assumptions, the related research has gradually formed three theoretical perspectives: institutional avoidance theory, institutional adaptation theory and institutional synergy evolution theory. The representative scholars of institutional avoidance theory are Hirschman (1970) [9] and Meyer (2001) [10]. This perspective holds that in the face of the "weak institutional environment" of the host country's lack of credit, unstable policies, regulation and imperfect laws, multinational enterprises take into account the inefficiency of the market and high transaction costs, or choose not to enter, shrink and exit strategies. The theory of institutional adaptation mainly follows the research ideas of Rosenzweig (1991) and others, and uses "institutional distance" to explain the influence of the pressure of "imitation isomorphism" of the host country's system on the entry mode of overseas investment market [11].

At present, due to the limitations of theoretical basis and research perspective, there are competitive academic viewpoints and contradictory research results. The traditional transaction cost theory pays too much attention to the adverse effects of transaction cost and "opportunism" on the market expansion efficiency of multinational corporations with monopoly advantages. From the perspective of real options, it emphasizes the effect of the choice of entry mode on the long-term value creation of enterprises' overseas investment market under the condition of environmental uncertainty. From the perspective of institutional basis, this paper grasps the important coordinating role of institutional environment on the decision-making and behavior of enterprises entering the overseas investment market. However, no matter which theoretical perspective it is based on, scholars believe that entry mode will have an impact on enterprise performance. Through the summary of the existing research theories, we put forward some research hypotheses: 
Hypothesis 1: equity entry mode is beneficial to improve enterprise performance.

\subsection{The Regulating Factors of Equity Entry Mode and Enterprise Performance}

Performance measurement can be divided into two categories: objective measurement and subjective measurement. Among them, the objective measurement indicators mainly include profit margin, return on assets, sales growth rate and other financial indicators, as well as the number of patent applications, the number of employees and other non-financial indicators; The subjective measurement indicators mainly include the performance satisfaction of the senior management of the company to the subsidiary and so on. The source of objective index is clear and relatively accurate, while the subjective index is the perceived performance evaluation of senior managers. Compared with objective performance, subjective measurement is more random. But at the same time, it may also be able to reflect some objective ways cannot observe the performance. Therefore, we speculate that the relationship between equity entry mode and corporate performance may be affected by the way of performance measurement.

In the early research on entry mode and enterprise performance, most of them take the enterprises of the United States, Japan, Europe and other developed countries as the main research object. In recent years, with the development of emerging economies, China, Central and Eastern Europe and other "emerging economies" have gradually become the main research areas. This is not only because of the huge differences in the social environment between developing and developed countries, but also because of the nearly half and increasingly important position of developing countries in absorbing global outward investment. Therefore, in this study, the source countries of sample enterprises are classified into two methods: one is to divide the source countries of sample enterprises into developed and developing countries; the other is to divide the source countries of enterprises into emerging economies and non-emerging economies.

Comparing the two entry modes of sole proprietorship and joint venture, there are many differences in the impact on the operation and management of the company. Woodcock and Beamish (1994) found that the performance of enterprises that choose new governance mode of greenfield to enter the host country market is better than that of enterprises that choose joint venture and other mixed governance mode, while the performance of enterprises that use joint venture mixed governance mode to enter the host country market is higher than that of enterprises that use acquisition entry mode to invest in overseas markets [12]. Pan, Li and Tse (1991) also believe that the entry mode of joint venture is higher than the operating performance brought about by acquisition [13]. Li and Guisinger (1991) takes the failure rate as the proxy variable of performance, the 
results show that the failure rate of newly-built sole proprietorship is the lowest, M \& $\mathrm{A}$ is the highest, and there is no significant difference in the failure rate of joint ventures [14]. Nitsch et al. (1996)'s research on Japanese foreign direct investment in Europe shows that the performance of newly-built sole proprietorship is better than that of joint venture, and the performance of joint venture is better than that of cross-border mergers and acquisitions [15]. Through empirical analysis, Zahra, Ireland and Hitt (2000) concluded that the adoption of high-control overseas investment market entry mode to enter the host country market has a significant positive effect on transnational performance [16]. Brouthers and George (2004) proposed that there is a discretionary relationship between overseas investment market entry mode and transnational performance [17]. From the perspective of transaction cost, in the case of newly-built sole proprietorship, the enterprise usually replicates its successful behavior in a foreign market, and the enterprise usually has suitable resources and assets, so the cost caused by resource demand is relatively small (Woodcock et al., 1994). Under the conditions of a joint venture, the costs of the joint venture include finding a suitable joint venture partner, losing sole control over the company's core resources (Kim and Hwang, 1992 [18], Kogut and Zander, 1993 [19]), and integrating the assets with the partner's assets, at the same time, the assets should be coordinated with the objectives and strategies of the joint venture. Therefore, the cost of a joint venture is higher than that of a sole proprietorship. From the perspective of management control, the cost of operation and management of a joint venture is higher than that of a wholly-owned enterprise because of the shared ownership, whether from the perspective of the initial negotiation on the right of control or in the later stage of business management (Beamish and Banks, 1987 [20]; Killing, 1983 [21]). In order to manage effectively, the joint venture must take a certain period of time to establish an appropriate management system, and requires the attention of the management of both sides. On the contrary, the newly-built sole proprietorship enterprise makes it have full control from the establishment to cancellation of the enterprise (Hill et al., 1990), which can also avoid the conflict of interests or mode of operation of both parties, and the performance should be relatively good [22]. Transaction cost theory and internalization theory believe that joint venture is an effective way to organize overseas markets, because it helps to solve the opportunism and uncertainty (Bearnish \& Banks, 1987) caused by international operation. Some scholars believe that having a cooperative investor in the host country is actually a mechanism, which helps to reduce the risk of institutional conflicts between overseas subsidiaries and the host government, and also helps to eliminate outsider disadvantages (Zaheer, 1995) [23]. However, Vanhonacker (1997) believes that the sole proprietorship enterprise does not need to negotiate with the partner, so the establishment speed of the sole proprietorship enterprise is faster than that of the joint venture, at the same time, the sole proprietorship enterprise does not need extensive technical guidance, and the sole proprietorship enterprise gives foreign investors the au- 
thority to establish, manage and protect production processes and processes to achieve cost savings [24].

Therefore, we believe that different ownership structure may affect the relationship between entry mode and performance.

The environment of the host country is one of the factors that must be considered when enterprises invest abroad. Therefore, the degree of development of the host country often directly affects the decision-making of enterprises' foreign investment. Different levels of development in host countries often bring different opportunities or challenges to entrants. Compared with developed countries, although emerging economies have drawbacks such as incomplete systems and large economic fluctuations, However, the rapid growth of outward investment in emerging economies, the strong intention to develop the capacity of local multinational enterprises, and the active participation of home governments in supporting outbound investment by local enterprises and creating an environment conducive to the inflow of foreign capital. All of these may bring development opportunities to the entrants. Over the past decade, emerging economies have become the top ten high-frequency keywords in model research. Therefore, this paper divides the types of host countries into emerging economies and nonemerging economies.

Hypothesis 2: performance measurement, source country type of sample enterprise, ownership structure and host country type can adjust the relationship between entry mode and enterprise performance.

\section{Method}

Comprehensive and systematic collection of relevant research literature is the basis to ensure high quality meta-analysis. What we collect is the research literature written in English, but not the Chinese research literature, mainly because the sample countries and regions in the English literature cover a wide range of countries and regions.

We ensure the systematicness and accuracy of document retrieval through the following four channels: first, In Cambridge Journals online, Elsevier SDOL, Emerald, JSTOR, Springer Link, EBSCO, Wiley-Blackwell and other databases, "entry mode", "joint venture", "Performance", "WOS" were used as keywords for literature retrieval. Second, the international authoritative management journals or journals with a large number of published articles are specially searched, such as Academy of Management Journal, Strategic Management Journal, Journal of International Business Studies and so on. Third, it carries on the special retrieval to the scholars who have been engaged in the research of dual ability for a long time to find the articles that accord with the topic; fourth, track the references of the comprehensive or empirical research articles to see if there are any omissions in the literature.

After rigorous screening, we obtained 97 effect values from 60 independent samples from 58 studies published between 1997 and 2018. 


\section{Result}

\subsection{Results of Heterogeneity Test and Meta Integration}

When the heterogeneity included in the study is evaluated by Q test and statistics, if $\mathrm{p}>0.1$ and $\leq 50 \%$, it shows that there is no obvious heterogeneity in the sample effect value, so the fixed effect model should be adopted. On the contrary, the random effect model should be adopted. In this study, 97 effect values were included for analysis, because $\mathrm{p}<0.1$, so the random effect model was used. Through the integration of the effect values, the results are as follows:

The weighted average effect value of uncorrected reliability is -0.03 (95\% CI: $-0.057-0.001)$, and the weighted average effect value of reliability correction is -0.003 (95\% CI: $-0.026--0.020$ ). It shows that there is a weak negative correlation between entry mode and performance, and it is statistically significant. This result shows that the equity entry mode has a weak negative impact on enterprise performance. Multinational corporations save costs by choosing entry mode, which may have a negative impact on the market share and employee satisfaction of their subsidiaries. This further demonstrates the weakness of transaction cost theory, that is, focusing on cost minimization rather than value maximization (zhao et al., 2004) [25]. At the same time, the equity entry mode has more resources than the non-equity entry mode, and the enterprise income may not completely cover the enterprise input in the short term, so there is a negative correlation between the equity entry mode and the enterprise performance.

\subsection{Publication of Bias Assessment Results}

There is evidence that statistically significant studies are more likely to be published, while some studies that do not have significant statistical results are reduced to "drawer files". This tendency leads to the use of published analysis to distort the true effect. Especially when the sample size of the study is small (Hedges, 1984) [26]. At present, the most commonly used bias detection methods are inverted funnel diagram method and insecurity factor method, but both of them cannot quantitatively detect publication bias. Beg method and Egger rule can be used to quantify the bias. In this paper, the classical Egger method and Begg method are used to test. The P value of Begg test was 0.545>0.05, indicating that there was no obvious publication bias, while the $\mathrm{P}$ value of Egger test was $0.917>0.05$, which also suggested that there was no obvious publication bias.

\subsection{Regulation Effect Analysis}

In this paper, we do not add the classification variable of the host country in model 1. In model 2, we add whether the host country is a classification variable of emerging economies. The results are shown in Table 1.

Comparing the results, we can find that the type of performance measurement in model 1 and model 2 has no significant effect on the relationship between equity 
Table 1. Meta-regression results of equity entry mode and enterprise performance.

\begin{tabular}{ccc}
\hline \multirow{2}{*}{ Table head } & \multicolumn{2}{c}{ Correlation-based calculation } \\
\cline { 2 - 3 } & Model 1 & Model 2 \\
\hline Performance measurement & 0.030 & 0.033 \\
Country of origin & $(0.354)$ & $(0.299)$ \\
(Emerging economies or not) & $-0.251^{\star *}$ & $-0.229^{* *}$ \\
Country of origin & $(0.003)$ & $(0.006)$ \\
(Developed or not) & $-0.268^{* *}$ & $-0.251^{\star}$ \\
Ownership structure & $(0.009)$ & $(0.013)$ \\
& -0.072 & $-0.081^{\star}$ \\
Host country type & $(0.070)$ & $(0.038)$ \\
& & $-0.067^{\star}$ \\
Constant & & $(0.035)$ \\
Variance & $0.271^{\star}$ & $0.286^{*}$ \\
Adj $\mathrm{R}^{2}$ & $(0.019)$ & $(0.011)$ \\
\hline
\end{tabular}

entry mode and enterprise performance. This shows that although the objective measurement of performance is relatively accurate, subjective measurement of performance has a certain randomness, but no matter which performance measurement method is used will not affect the relationship between equity entry mode and enterprise performance.

Whether the country of origin of the sample enterprise is an emerging economy or not has a significant negative regulatory effect on the relationship between equity entry mode and enterprise performance. The possible reason for this result is that, despite the rapid growth of outward investment in emerging economies, the capacity development intentions of local multinationals are strong. However, this strong development motivation may promote the blind expansion of enterprises, which is not conducive to the improvement of enterprise performance and even the risk of investment failure. On the other hand, the home country government, as an emerging economy, is actively involved in supporting the outbound investment of local enterprises, but the support of the home country government may not be conducive to the adaptation and survival of enterprises in foreign markets. Therefore, it may not be conducive to the performance of OFDI enterprises.

Whether the country of origin of the sample enterprise is a developed country or not also has a significant negative regulatory effect on the relationship between equity entry mode and enterprise performance. This shows that having a good home country foundation does not ensure that enterprises can achieve better performance in the international market. It may even affect the performance of enterprises because of the great differences between the economic and institutional environment of the host country and the environment of the home country.

Without considering the type of host country, the impact of ownership struc- 
ture on the relationship between entry mode and enterprise performance is not significant, but whether the host country is a classified variable of emerging economies, Ownership structure has a significant negative impact on the relationship between entry mode and enterprise performance. This may be because the rapid economic development of emerging economies has led to rapid changes in its system, culture and other aspects of society. The rapidly changing external environment has brought many uncertain factors and risks to the survival and development of enterprises. At the same time, many emerging economy countries still have the problem of imperfect laws and systems. Therefore, when an enterprise enters an emerging economy, if it chooses the sole proprietorship entry mode, the risk of excessive concentration may have a bad impact on the enterprise performance, while the joint venture entry mode can enable the entering enterprise to share the risk with its partners. The joint venture model also helps to reduce the risk of institutional conflicts between overseas subsidiaries and host governments and to eliminate the disadvantage of outsiders ( $\mathrm{Za}$ heer, 1995).

\section{Conclusion and Enlightenment}

\subsection{Conclusion}

This paper systematically codes 58 empirical literatures on the relationship between entry mode and enterprise performance from 1997 to 2018 . By using the method of meta-analysis, this paper makes a systematic analysis of the relationship between equity entry mode and enterprise performance and the factors that may affect the relationship between them, and draws the following main conclusions: in general, there is a significant negative correlation between equity entry mode and enterprise performance. Compared with the non-equity entry mode, the equity entry mode invests more resources, and the enterprise performance may not be able to cover the resources invested in the short term. At the same time, some enterprises choose foreign direct investment, often in order to seek the long-term survival and success of enterprises, so the maximization of profits in the short term may not be the main goal of enterprises. Although the conclusion of the integration analysis is that there is a significant negative correlation between the equity entry mode and the performance, the heterogeneity test results in the integration analysis are significant, indicating that there is still obvious heterogeneity. That is to say, there are important regulatory variables that form the difference between equity entry mode and performance. Therefore, this paper further makes a meta-regression analysis of the regulatory variables which may affect the relationship between the two. From the results of meta-regression analysis, we can draw the following conclusions: the relationship between entry mode and performance is regulated by the source country type, ownership structure, company size and host country type of the sample enterprise. These factors have a significant negative impact on the relationship between equity entry mode and enterprise performance. 


\subsection{Limitation}

We mainly analyze the overall effect of entry mode on enterprise performance. Although in the process of analysis, this paper follows the previous practice and selects the relevant empirical research from the first-class journals. However, this does not completely rule out the possibility that there may be some highly relevant and important theoretical research in journals other than these journals. At the same time, this paper is based on the existing empirical research is mainly based on the ownership of the entry model, other entry models based on franchise or license management may also be related to enterprise performance. However, it is not discussed in this study, which can become a direction of future research.

\section{Acknowledgements}

First of all, I would like to thank my respected mentor, Professor Pan Zhen. The grace of teaching and the period of boxing are unforgettable for the rest of my life. Whether it is the usual study and life or the whole graduation thesis creation process, Mr. Pan gave me great help. From the topic of the thesis to the final completion of Mr. Pan's meticulous and patient guidance to me, I still remember the situation when I went to Mr. Pan to discuss the literature, viewpoint, structure, data and so on. Although very busy, Mr. Pan is patient to give me guidance every time. Once again, I would like to thank Mr. Pan for his help in my life and study. Secondly, I would like to thank the lovely students, in our studies we encourage each other, support each other in life, formed a profound friendship. Let me feel your concern and help in my life and study all the time. I would also like to thank my counselors and the leading teachers in the school, thank all the friends I know during my graduate school, you make my life full of joy! Finally, I would like to thank my family, as always, for their support and encouragement. You will always be the driving force for me to move forward.

The completion of graduation thesis is not only the examination and assessment of my graduate study career, but also the opportunity for me to examine myself and improve myself. Thank you for my respected teachers and lovely classmates who have accompanied me for three years. Let me grow rapidly in these three years. In the future, I will face life more strongly and optimistically. Here, I would like to express my heartfelt thanks to all the teachers, classmates, friends and family who have helped me.

\section{Conflicts of Interest}

The author declares no conflicts of interest regarding the publication of this paper.

\section{References}

[1] Wind, Y. and Perlmutter, H. (1977) On the Identification of Frontier Issues in International Marketing. Columbia Journal of World Business, 12, 131-139. 
[2] Stopford, J.M. and Wells, L.T. (1972) Managing the Multinational Enterprise/Organization of the Firm and Ownership of the Subsidiaries. Basic Books, New York.

[3] Buckley, P.J. and Casson, M.C. (1976) The Future of the Multinational Enterprise. Macmillan, London. https://doi.org/10.1007/978-1-349-02899-3

[4] Dunning, J.H. (1977) Trade, Location of Economic Activity and the MNE: A Search for an Eclectic Approach. In: Ohlin, B., Hesselborn, P.O. and Wijkman, P.M., Eds., The International Allocation of Economic Activity, MacMillan, London, 395-418. https://doi.org/10.1007/978-1-349-03196-2_38

[5] Anderson, E. and Gatignon, H. (1986) Modes of Foreign Entry: A Transaction Cost Analysis and Propositions. Journal of International Business Studies, 17, 1-26. https://doi.org/10.1057/palgrave.jibs.8490432

[6] Williamson, O.E. (1975) Markets and Hierarchies: Analysis and Antitrust Implications. The Free Press, New York.

[7] Williamson, O.E. (1985) The Economic Institutions of Capitalism. Free Press, New York.

[8] Kogut, B. (1991) Joint Ventures and the Option to Expand and Acquire. Management Science, 37, 19-33. https://doi.org/10.1287/mnsc.37.1.19

[9] Hirschman, A.O. (1970). Exit, Voice and Loyalty. Harvard University Press, Cambridge.

[10] Meyer, K.E. (2001) Institutions Transaction Costs, and Entry Mode Choice in Eastern Europe. Journal of International Business Studies, 32, 357-367. https://doi.org/10.1057/palgrave.jibs.8490957

[11] Rosenzweig, P. and Singh, J. (1991) Organizational Environments and the Multinational Enterprise. Academy of Management Review, 16, 340-361.

https://doi.org/10.5465/amr.1991.4278953

[12] Woodcock, C., Beamish, P. and Makino, S. (1994) Ownership-Based Entry Mode Strategies and International Performance. Journal of International Business Studies, 25, 253-273. https://doi.org/10.1057/palgrave.jibs.8490200

[13] Pan, Y.G., Li, S.M. and Tse, D.K. (1999) The Impact of Order and Mode of Market Entry on Profitability and Market Share. Journal of International Business Studies, 30, 81-104. https://doi.org/10.1057/palgrave.jibs.8490061

[14] Li, J. and Guisinger, S. (1991) Comparative Business Failures of Foreign Controlled Firms in the United Stated. Journal of International Business Studies, 22, 209-224. https://doi.org/10.1057/palgrave.jibs.8490300

[15] Nitsch, D., et al. (1996) Entry Mode and Performance of Japanese FDI in Western Europe. Management International Review, 6, 27-43.

[16] Zahra, S.A., Ireland, R.D. and Hitt, M.A. (2000) International Expansion by New Venture Firms: International Diversity, Mode of Market Entry, Technological Learning and Performance. Academy of Management Journal, 43, 925-950. https://doi.org/10.5465/1556420

[17] Brouthers, K.D. and Nakos, G. (2004) SME Entry Mode Choice and Performance: A Transaction Cost Perspective. Entrepreneurship Theory and Practice, 28, 229-247. https://doi.org/10.1111/j.1540-6520.2004.00041.x

[18] Kim, W.C. and Hwang, P. (1992) Global Strategy and Multinationals' Entry Mode Choice. Journal of International Business Studies, 1, 29-53. https://doi.org/10.1057/palgrave.jibs.8490258

[19] Kogut, B. and Zander, U. (1993) Knowledge of the Firm and the Evolutionary Theory of the Multinational Corporation. Journal of International Business Studies, 
24, 625-645. https://doi.org/10.1057/palgrave.jibs.8490248

[20] Beamish, P.W. and Banks, J.C. (1987) Equity Joint Ventures and the Theory of the Multinational Enterprise. Journal of International Business Studies, 18, 1-16. https://doi.org/10.1057/palgrave.jibs.8490403

[21] Killing, J.P. (1983) Strategies for Joint Venture Success. Praeger, New York.

[22] Hill, C.W.L., Hwang, P. and Kim, W.C. (1990) An Eclectic Theory of the Choice of International Entry Mode. Strategic Management Journal, 11, 117-128. https://doi.org/10.1002/smj.4250110204

[23] Zaheer, A. and Venkatraman, N. (1995) Relational Governance as an Interorganizational Strategy: An Empirical Test of the Role of Trust in Economic Exchange. Strategic Management Journal, 16, 373-392. https://doi.org/10.1002/smj.4250160504

[24] Vanhonacker, W. (1997) Entering China: An Unconventional Approach. Harvard Business Review, 75, 130-140.

[25] Zhao, H., Luo, Y.D. and Suh, T. (2004) Transaction Cost Determinants and Entry Mode Choice: A Meta-Analytics Review. Journal of International Business Studies, 35, 142-160. https://doi.org/10.1057/palgrave.jibs.8400106

[26] Hedges, L.V. (1984) Advances in Statistical Methods for Meta-Analysis. Issues in Data Synthesis. New Directions for Program Evaluation, 24, 25-42.

https://doi.org/10.1002/ev.1376 